\title{
A Study on the Cultivation of Female Students Ability in the Girl's Athletic Association-Taking Qingdao University of Science and Technology as an Example
}

\author{
Xiaodong $\mathrm{Chu}^{1} \&$ Xiaowen $\mathrm{Liu}^{1}$ \\ ${ }^{1}$ Institute of Physical Education, Qingdao University of Science and Technology, Qingdao, China \\ Correspondence: Xiaodong Chu, Institute of Physical Education, Qingdao University of Science and Technology, \\ No.99 Songling Road, Qingdao, China. E-mail: xiaodongchu@126.com
}

Received: February 6, 2017

Accepted: February 27, 2017

Online Published: March 24, 2017

doi:10.5539/ass.v13n4p125

URL: https://doi.org/10.5539/ass.v13n4p125

\begin{abstract}
This paper studied the status of o the Girl's Athletic Association in the matter of the organization and function. Some problems in development progress are analyzed, such as the number of members reduced, the chaos of organization construction, the shortage of fund. Some proposals and countermeasures are putted forward from strengthen and improving the organization system construction, carrying out rich and colorful activities, the funding, hiring teachers and the association responsible person, increasing the association activity time, changing the content of activities To play an important role in the aspects of actively encouraging and guiding the female classmate association activities, and promoting the all-round development of girl's ability.
\end{abstract}

Keywords: ability cultivation, Girl's Athletic Association, organizational construction, strategy

\section{The Established Background of the Girl's Athletic Association in Qingdao University of Science and Technology}

Now, with cognition and attitude on sports have a huge change, college student take more attention on strengthening their physical quality. Under the background of new era, many female sports enthusiasts have emerged, they expect to have more opportunities to participate in sports activities, but no organization and opportunity like this. In this context, Li Cheng, one of the Qingdao University of Science and Technology students, produced the idea that developing the girl's athletic association. At firstly, she developed the roommate and students. To later, the number is more and more, and finally the Qingdao University of Science and Technology girl's athletic association was established in April 2005.

The chief sponsor of the Qingdao University of Science and Technology girl's athletic association had a total of 11 students, such as Li Cheng, Xiaochen Liu, Cuicui LI, and so on. At the beginning of the association was set up, the promoters into Li Cheng was the first chairman of the Qingdao University of Science and Technology Girl's Athletic Association, the founder Xiaochen Liu, Cuicui Li was vice president, the sponsor Yanhong Wang was outreach minister, the sponsor Shuqing Xie was publicity minister, the founder Xiumei Mou was secretary, Wei Li served as Minister of planning launched.

In order to attract the majority of women's sports enthusiasts to participate in a variety of campus sports activities, increase students' interests and hobbies, the Girl's Athletic Association organized a variety of sports events. The association also encouraged and helped the masses of women's sports fans to openly take on the stadium, active, moving up, unite. Simultaneously, the association created conditions, so that women's sports fans dared to stand on the stadium for releasing their own enthusiasm, better participate in sports activities. At the same time, the association hired tutors to give technical guidance for guaranteeing the security and technical, so that the majority of women sports enthusiasts participated in exercise at ease. Association also be concerned about the physical and mental health of the members, for creating a healthy and beautiful image of youth, exercising a healthy body, honing the tough character of members. The association was committed to the friendly association with other societies, will strengthen the links with other school sports enthusiasts, exchange of experience and lessons. At the same time, the development of the Girl's Athletic Association was also facing new opportunities and challenges. So this paper is based on the background of the Qingdao University of Science and Technology Girl's Athletic Association 


\subsection{Purpose and Significance of the Study}

Qingdao University of Science and Technology Girl's Athletic Association was founded in 2005. For its original intention, the establishment of the association is very meaningful and very worthy of our attention and thinking. First of all, it is a spontaneous formation of Girl's Athletic Association, and it was headed to launch by a hobby movement of female student Li Cheng. This reflects that some out of the ordinary young women are cultivated under the new era and a new trend. They are different from the traditional female image which is rigid and conservative, they love sports and eager to expand their team and find more like-minded people, and hope to provide a platform for more women sports enthusiasts. All of this is a spirit and platform support for women's sports enthusiasts. Secondly, the Girl's Athletic Association has been launched with the support and recognition of the school, it also reflects the school is to keep pace with the times, an open mind to accept the society inject more vitality into the Qingdao University of Science and Technology. Therefore, the study of Girl's Athletic Association has certain significance and value of depth. We need to standardize association management, and make the activities more diverse, to attract more women to participate in sports enthusiasts, to reach everyone consciously to participate in physical exercise and to enrich the cultural life of the campus. At the same time, the training can cultivate the organizer's ability of organization and management, and increase the awareness of the members, to improve their health indicators.

\subsection{The Present Management Situation of the Girl's Athletic Association in China}

\subsubsection{Rapid Increase in the Number of Associations}

In recent years, with the national education reform, strengthened and improved ideological and political education as an important and urgent strategic was tasked on the agenda, the aim was that comprehensively promoting quality education, implementing "prospering the nation with science and education" strategy and talent strategy". On request of cultivating Chinese socialism characteristics qualified builders and reliable successors, College Students' Sports Association work was strengthened and the improved. The development of College Students' Sports Association has been paid more attention by the state, society and universities (Zuo, \& Xie, 2003).

\subsubsection{Serious Imbalance in the Structure of the Association}

In accordance with the content division, University Sports Associations can be divided into sports, football, volleyball, skating and so on. But the number of all kinds of associations and activities carried out in number but far, and a serious imbalance in society structure, such as the number of football, sports and other public sports association increased rapidly, and relatively perfect organizational structure. Others less popular activities are simple in structure. The activities of the sports associations are relatively simple, only focused on some internal competition and guidance internally $(\mathrm{Xu}, 2003)$. This has led to the low-level duplication of college sports associations, such as the repeated association of some football equivalent projects, or the overlap of activities such as outdoor associations and rock climbing associations. At the same time, it will cause the blind competition for resources, such as some associations in order to fight for the members and the venue and the unpleasant friction (Huang, 2003). There will also be cohesion within the association is not strong, the lack of innovation and creativity, and other issues.

\subsubsection{Association Lacks Professional Guidance}

University Sports Associations rarely get professional guidance. Some associations do not even have professional guidance teachers. The most of existing guidance teachers are school group cadres. They only provide assistance and guidance from organizing activities. And the guidance ability and scope are limited (Fan, $\mathrm{Gu}, \&$ Wang, 2000). One reason is that many teachers own that one cannot be in two places at once facing the pressure of the teaching and research, On the other hand, school without the corresponding incentive mechanism to guide the work of the association.

\subsubsection{Poor Continuity of the Association, Sustainable Development Capacity Is Weak}

According to the survey results of some societies, most of the students think that the continuity of the association is poor, among of them, they think that the liquidity of the college students' association is too large. Through the study of some representative associations found that most charge person of the association are only one year. At the same time, the ratio of adhering to organize the activities is low each semester. Some of the association is not strong vitality, is exist in name only. 


\section{Situation and Analysis of Qingdao University of Science and Technology Girl's Athletic Association}

\subsection{Organization Setting}

The organization of the association is composed of the tutor, the president, the ministers and the captain. The person in charge at all levels shall be elected or elected democratically. The person responsible for the nomination proposal dismissal, need the approval of the number of main member institutions by $2 / 3$ before implementation, and the president of institutions respects the decision. The executive agency includes operating duty, organization department, propaganda department, technical department, secretary, ministry of construction network.

Table 1. Executive Council of Girl's Athletic Association

\begin{tabular}{|c|c|c|c|}
\hline $\begin{array}{c}\text { Executive } \\
\text { agency }\end{array}$ & Position setting & $\begin{array}{c}\text { Number of } \\
\text { people }\end{array}$ & Operating duty \\
\hline Operating duty & Chairman & 1 & $\begin{array}{l}\text { The overall plan as a whole, personnel arrangement, and } \\
\text { responsible for the overall plan spending in the activities organized } \\
\text { by the general assembly, held on the main responsibility of the } \\
\text { Basketball Association out and in. }\end{array}$ \\
\hline & Vice chairman & $1-2$ & Responsible for the implementation of specific work plan. \\
\hline $\begin{array}{c}\text { Organization } \\
\text { department }\end{array}$ & $\begin{array}{c}\text { Minister } \\
\text { Vice-minister }\end{array}$ & $\begin{array}{c}1 \\
1-2\end{array}$ & $\begin{array}{l}\text { To ensure the normal and orderly internal association activities } \\
\text { sponsored by the Department responsible for the association of } \\
\text { sports events, do a good job organize and coordinate the work in } \\
\text { the game, teams attended the Basketball Association meeting; } \\
\text { arrange the playing field; arrangements and adjustment all players } \\
\text { game time; layout of venues and maintain order; statistical and } \\
\text { save the game data. }\end{array}$ \\
\hline $\begin{array}{l}\text { Propaganda } \\
\text { department }\end{array}$ & $\begin{array}{l}\text { Minister } \\
\text { Vice-minister } \\
\text { Manager }\end{array}$ & $\begin{array}{c}1 \\
1-2 \\
\text { Some }\end{array}$ & $\begin{array}{l}\text { Mainly responsible for publicity of the activities, internal members } \\
\text { and association of communication and event report and schedule } \\
\text { of production and post work. }\end{array}$ \\
\hline $\begin{array}{c}\text { Liaison } \\
\text { department }\end{array}$ & $\begin{array}{l}\text { Minister } \\
\text { Vice-minister } \\
\text { Manager }\end{array}$ & $\begin{array}{c}1 \\
1-2 \\
\text { Some }\end{array}$ & $\begin{array}{l}\text { The school sports sponsorship arrangements related activities is } \\
\text { mainly responsible for the association of small internal activities } \\
\text { and the organization of the Basketball Association. }\end{array}$ \\
\hline $\begin{array}{c}\text { Technical } \\
\text { department }\end{array}$ & $\begin{array}{l}\text { Minister } \\
\text { Vice-minister } \\
\text { Manager }\end{array}$ & $\begin{array}{c}1 \\
1-2 \\
\text { Some }\end{array}$ & $\begin{array}{l}\text { In the later work is mainly responsible for the referee before the } \\
\text { game and sports competition rules and guidance; the formulation } \\
\text { and interpretation of the game rules; arrangement referee; training } \\
\text { of sports referee; arrange and record the data match game. }\end{array}$ \\
\hline Secretary & $\begin{array}{c}\text { Minister } \\
\text { Vice-minister }\end{array}$ & $\begin{array}{c}1 \\
1-2 \\
\text { Some }\end{array}$ & $\begin{array}{l}\text { Mainly responsible for the registration and management of } \\
\text { membership information, organized and recorded system of } \\
\text { conference, the drafting and revision of the relevant system; } \\
\text { coordinating the work of various departments and activity records } \\
\text { and data and budget approval. }\end{array}$ \\
\hline $\begin{array}{l}\text { Ministry of } \\
\text { construction } \\
\text { network }\end{array}$ & $\begin{array}{l}\text { Minister } \\
\text { Vice-minister } \\
\text { Manager }\end{array}$ & $\begin{array}{c}1 \\
1-2 \\
\text { Some }\end{array}$ & $\begin{array}{l}\text { To be responsible for the media communication of the association } \\
\text { and the members of the society, and to set up a temporary working } \\
\text { group when necessary, to be responsible for a certain work. }\end{array}$ \\
\hline
\end{tabular}

\subsection{Personnel Appointment and Selection}

The chairman of the current session of the nomination by the previous president, and finally by the full assembly to attend the vote on behalf of 2/3; Minister nominated by the president, the General Assembly attended the vote on behalf of more than $2 / 3$;

The basketball activities completed by each department of coordination and cooperation, the association will award month outstanding manager at the end of the month, at the end of each semester, school should award outstanding director, outstanding cadres and sports outstanding contribution award, given honorary certificate and issued by the Federation of student groups.

\subsection{Organizational System}

The financial system: the funding sources of association mainly from social sponsorship and funding and membership to the Communist Youth league. Secretariat is responsible for internal finance, the required funds were planned by the Secretary Ministry, submitted to the presidium for approval, valid invoice (or receipt) 
reimbursement. The account should be open, transparent. All members can supervise and put forward the problem.

The meeting system: at the end of each semester, a plenary meeting was convene. All members shall not be absent without special reasons. The meeting mainly on the annual work summary and preliminary school work plan, the selection of outstanding sports director, outstanding cadres and outstanding contribution award. In term midway, the major event of things be decided by the presidium to discuss all members. All members shall not be absent without special reasons. Every month, cadres meeting should be held at least once, all the cadres shall not be absent without special reasons. The meeting mainly on the preparatory work is summarized, the next phase of the work plan, and the selection of the monthly outstanding director; each department according to the needs of the work, decide.

The activities carried out by the association should be followed in strict accordance with the relevant provisions and procedures of the school. Prior to submit a detailed plan and declare, after approval can be carried out, after the summary record.

\section{The Function Present Situation and Analysis of Qingdao University of Science and Technology Girl's Athletic Association}

\subsection{Exercise Strong Communication Skills}

The Girl's Athletic Association as an organization of many members, the interior is equal, relaxed, just like a small society, between the member to more frequent exchanges, training of members of the communication ability of the more fully.

The Girl's Athletic Association can make use of the advantages of their own student associations, to break the bottleneck of the exchange of classes, and actively create opportunities for contact their members and social, open up the channels of communication with the community.

The Girl's Athletic Association can help members from school to society and achieve the purpose of serving the society, to promote its members to make full use of the broad stage of society and rich resources, to strengthen the training of occupation ability, enhance the members of the association of social adaptability and communication skills.

\subsection{Setting Up A Good Team Spirit}

The internal members of the Girl's Athletic Association is an equal relationship. In the activities, they can speak freely, to exchange views on equality, publicly clarify their own point of view, has a strong democratic atmosphere. All of this helps to cultivate students' democratic consciousness. In carrying out activities, from the planning of the activities to the funds, equipment, venues and other specific issues, we need to work together to cultivate the spirit of fair competition and cooperation with others (Wang, \& Shen, 1999).

\subsection{Active Campus Life}

Today, the way of our university campus cultural activities is still relatively simple, such as college organizations, student organizations, or the organization of associations. Colleges and student union organize large-scale activities have a certain degree of time limit, generally an annual. Therefore, or the main role is small association in most of the time. The Girl's Athletic Association activity has great flexibility, it can be a small range of activity game, also can be a series of activities for a long time, which greatly enrich the students' extracurricular cultural life, with distinctive characteristics, strong pertinence, rich and colorful activities to attract the majority of students to participate in. It can be seen that the activities of the Girl's Athletic Association are active in the daily life of students, and play an important role in the construction of campus culture. In the activities, they not only exercise their own, but also to their own value has been reflected.

\subsection{Exercise Effect}

The Girl's Athletic Association organized the students with the common interests and hobbies. This needs that students spontaneously organized together, is not confined to the teaching plan and syllabus, a variety of forms, rich and colorful content, provides the possibility for the comprehensive development of talent cultivation. It reflects that the value orientation of College Students' sports has been transformed into entertainment, communication, competition and other aspects, has developed to a higher level. The amateur sports activities of college students show the characteristics of diversity, integrity, initiative and instability (Jiang, \& Shen, 1995).

\subsection{Extension of Classroom Teaching}

Under the guidance of the teachers and the students, the physical teachers teach the physical knowledge, 
technology and skills according to the educational plan and the physical education syllabus. Because the sports classroom teaching is the form that dozens of different personality students together. It is a great limitation that the principle of teaching students in accordance of their aptitude (Dong, 2004). It is very unfavorable for discovering and cultivating sports talents. Activities planned to carry out by the Girl's Athletic Association can consolidate the classroom teaching skills, expand and deepen the content of classroom teaching, more conducive to broaden their horizons, individualized.

\subsection{Develop the Habit of Exercising.}

College students are in the critical period of growth and development. Plasticity of the body is very strong. Many parents and students have realized that health is very important. Parents should encourage their children to participate in sports activities. Students actively participate in Sports Association. So the Girl's Athletic Association is a very good platform. Making a good foundation of health in the Girl's Athletic Association activities and school sports teaching, it is not only need to complete their studies and happy life of the students at the stage, but also their lifelong health needs (Chen, 2006). But foundation of personal physical health in the age of the students is not once and for all. So good habits formed in the Girl's Athletic Association activities of physical exercise and health awareness and ability, will benefit students for life.

\section{Problem and Actuality of Qingdao University of Science and Technology Girl's Athletic Association}

\subsection{The Decrease of the Registrations}

Qingdao University of Science and Technology Girl's Athletic Association has been established for 12 years. It could be said to be a qualified students interested in the community. In accordance with the normal state of development, a, interest association team should be quite strong in the face of perfect system and facilities, after the development of 12 years. But we have seen the opposite results from the years of data. Since the association was founded in 2005, except the number of members were added to 74 people in 2007 , the numbers of registers are less than 35, and even drop to 11 people in the year of 2009. So it is not difficult to rule out that the number of members in 2007 reached a peak because the membership fee was reduced from 15 to 10 .

\subsection{Organizational Construction Sector Confusion}

From the data over the years, we can also see that the organization does not follow a certain organizational structure, the composition of the Department has been changing. At the beginning of the association, in addition to the president and vice president, under the various departments were setted up, such as of the Secretariat, the Propaganda Department, liaison department, technical department. It is not difficult to see that the association made efforts to standardization, scale and systematic management of association development at the beginning. Data of 2013 shows that the association was a total of 28 people, in addition to the president, other departments has been canceled. We can also see that the Association changed its name from the Girl's Athletic Association to the Sports Association in 2012. According to various performance, we can say that this association in the process of development is to explore a more suitable road for them to survive in the competition and the high school association, and in the organized construction and the tendency to association object what they think is beneficial to the association to adjust. But we can also say that the association in the development of the road has gradually deviated from the founder's original intention, if the Girl's is not deleted in the name of Athletic Association. It would be not the so-called "girl's sport enthusiasts association, the majority of women's sports enthusiasts to exchange the bridge and the link and the association for the expansion of the object is to create a deviation from the original association (Cao, 2008). Perhaps like the current sports association president Zhihui Liu stressed the "freedom", the sports association itself is for the majority of people who love sports to provide a platform for communication, do not need so many departments. People in the association are straightforward style, do not want to do something deliberately have some restrictions on the mechanism. It can be said that an association showed different trend under different people "rule", but no matter what kind division of each party in some way. We can not say that each argument, or the system has the absolute right and wrong. But the long-term survive, an association must have the core it is the spirit of this association. One principle runs by this, it is fresh and vigorous.

\subsection{Association Operating Funds Tight}

Zhihui Liu, President of the Girl's Athletic Association, said that there was a problem: the association did not ball. As a sports association, their sports could not get good supply and security. She said that although we received dues, but the money was not in our hands. We often played the game, when the ball was broken, we needed to buy, so we would apply for funds, hoping to set aside some of the cost to buy the ball. But it was not approval without reason. The association did not have the ball so we were playing with their own, and now can 
only be so. Association has not the source of funds and equipment, but some ways are not so effective in the actual operation of the process. But we can also see that facing the financial problems, the association did not attempt to seek sponsorship and other way. When finding that "system" was not affect no longer, it was sitting still waiting for death that no action was carried out in a way.

Everything is not going smoothly, roughly. Perhaps, each association has presentation of prosperous, but also has aching difficulties behind. Problems continuously exposed Association in the development process of association, let us love dearly and introspection (Ma, Gao, Zhou, \& et al., 2006). Survival of association is very simple and also very difficult. In fact, the vitality of society depends more on the attitude of the core leadership and positive active mind. Their own piece of heaven and earth were developed $t$ in a bandage, the essence of the problem can be seen out of the complained layers, finding a way to solve the problem (Sun, 2007). So the association is not only fanciers, interest associations also need good community operators and managers.

\section{The Future Development Strategy of Qingdao University of Science and Technology Girl's Athletic Association}

\subsection{Strengthen and Perfect the Organization System Construction}

Although the Girl's Athletic Association activities determined by their plan, but they accept the guidance of the school league and student. Various sports activities are carried out on purposeful and meaningful. The association positive guided the establishment and improving and perfect the management system according to the actual situation. The more activities, associations are more active. They will attract a mass of the students, the team is relatively large. Therefore, it is an important measure to promote the development of school physical education which sets up the management system and long-term development plan (Skoclpol, 1979). No can be accomplished without norms or standards. Association does not have strict rules and regulations, members do not have the strict discipline, not only to make the members of the discipline lazy, but also to bring chaos to the entire association and helping the formation of bad wind. Therefore, it is necessary to improve the management system of the association, optimize the management mode, so that the association management standardization, regular activities, rapid development. To make the Girl's Athletic Association of Qingdao University of Science and Technology develop in a healthy and orderly way (Salamon, 1999).

\subsection{Association of Rich and Colorful Activities, Increase Attraction}

The Girl's Athletic Association need to elaborate organization activities, give full consideration to all the members. In the activities of the content and form, to the novel, warm, comprehensive care and relaxation, to maximize the increase of association of appeal. Not only making every member of the association loves the activities, and feels the warmth of the collective in the process, but also let them feel the full value of their own, and allow more sports enthusiasts to participate in society, to change less situation of the members.

\subsection{Activity Funds}

The shortage of funds is still the one of the important factors which restrict the Girl's Athletic Association activities. Although each member has to pay a portion of dues, but this is far from enough daily activities and equipment purchase. So it is necessary to seek corporate sponsorship. In order to get corporate sponsorship, we must try to expand the scale of the activities of the association to improve the advertising effect. According to the actual situation of the Girl's Athletic Association summarizes the activities, develops a quarter, semester or year activity plan, reasonable arrangements for the activities of the time and place, carefully designs activities. The activities of the organization before the publicity work, to create a momentum, expand the time span and the effect of advertising, attracting business sponsorship. At the same time, it can also be appropriate to increase the amount of membership dues from members to ensure the normal operation of the association. Each member of the membership dues are also used in the members of their own body, not only to meet their own interests, but also exercise the body, so the appropriate increase in the amount of membership dues can be understood and realized.

\subsection{To Hire Teachers and Leaders}

The Girl's Athletic Association should choose those students that have a sense of responsibility, capacity of management and a greater interest to the Association as the leaders of the association. Meanwhile, hiring professional guidance teachers not only make the association more professional and effective but also instruct member's sports professionally. The Girl's Athletic Association is managed by the school committee as an independent organization. The school committee should strengthen the management of the association, which can improve the positivity of the teachers and the leaders to promote the Girl's Athletic Association for developing more healthily and orderly by some ways such as making policy of rewards and punishments, 
rewarding teachers and leaders.

\subsection{To Increase the Activities of the Association and Enrich Its Activities}

The Girl's Athletic Association should try to increase the number of activities and time to make members participate in each other by spending fully spare time and holidays. The activities of the association are not limited to the training and competition of the project but engaging in a number of student fraternities or hiring experts for carrying out relevant knowledge seminars to increase communication and communication between the various associations. These activities can further enhance the capacity of members to promote the association to reach a higher level.

\subsection{To Change the Content of Activities for Turning Entertainment into A Major Activity}

Nowadays, like the traditional student sports association the content of the Girl's Athletic Association's activities is simplex and its mode of operation has been fettered. Consequently, Reforming the teaching and training content and improving the fun of sports are essential to reduce the difficulty and increase the aesthetic feeling for not only conforming to the trend of the times but also meet the desire of college students to attract more female students. At the same time, paying attention to many factors including fitness knowledge, methods, projects can enable the association to develop more deeper than those traditional student sports association.

\section{Conclusion}

The Girl's Athletic Association provides a broad space for the students to make the campus culture become full of youthful spirit. It can not only actively encourage and guide students to carry out the activities of the association, but also promote the all-round development of students, which is an organic part of the campus. The Girl's Athletic Association is a product of the development of modern education and an important part of physical education in universities. Meanwhile, it plays an important role in strengthening students' health and cultivating students' health consciousness.

We should attach great importance to the organization of the association and the role of Girl's Athletic Association to take a comprehensive and healthy development for the association. Moreover, we also should adapt its characteristics and current situation to strengthen the support, management and guidance of the association.

The saying that "The interest is the best teacher" means the interest can lead a person to love something crazily and guide him to get close to those people who have the same interests. Therefore, we can say that as for the association, people who can gather in this place have the same hear. What can we do is how to let these people strength together and renew vigor to produce the maximum impact with efforts of all people.

\section{References}

Cao, Y. (2008). The Present Situation and Countermeasures of the Development of College Sports Associations in Jiangsu. Journal of Capital Institute of Physical Education, (8), 96-100.

Chen, W. D. (2006). The Influence of the Sports Association on the Lifelong Sports Consciousness and Ability Cultivation of College Students. Journal of Minxi Vocational and Technical College, (3), 93-95.

Dong, X. Q. (2004). On the Influence of the Activities of Physical Education Fans 'Associations on Universities' Physical Education Teaching. Sport Science and Technology, (2), 75-76.

Fan, L. R., Gu, M. R., \& Wang, H. Z. (2000) A Nationwide Survey on Students 'Physical Activities after School. China Sport Science, 20(2), 7-11.

Huang, Y. L. (2003) Discussion on Sports Associations in China. Beijing: Beijing Sport University.

Jiang, Q. Y., \& Shen, M. D. (1995). The Basic Characteristics of the University Community Activities and Working Methods. Journal of Hubei Sports Science, (4), 81-83.

Ma, X. D., Gao, Q. J., Zhou, Y., \& et al. (2006). Investigation Research on the Function and Significance of Sport Corporation in Universities and Colleges. Journal of Beijing Sport University, 29(2), 227-228.

Salamon, E. (1999). The Rise of the Third Sector. Foreign Affairs.

Skoclpol, T. (1979). State and Social Revolution. Cambridge University Press.

Sun, X. B. (2007) On the Influence of College Sports Association on School Physical Education. Sports Teachers, (5), 29-40.

Wang, C. Y., \& Shen, J. H. (1999). Reflections on the Development of Extracurricular Sports Activities in China. Journal of Shanghai University of Sport, (4), 61-64. 
Xu, Z. H. (2003). A Preliminary Study on the Materialization of Sports Associations. Guangzhou: Guangdong Higher Education Press, 14-15.

Zuo, R. Y., \& Xie, J. (2003). The Role of University Sports Social Organizations. China School Physical Education, (5), 52-53.

\section{Copyrights}

Copyright for this article is retained by the author(s), with first publication rights granted to the journal.

This is an open-access article distributed under the terms and conditions of the Creative Commons Attribution license (http://creativecommons.org/licenses/by/4.0/). 